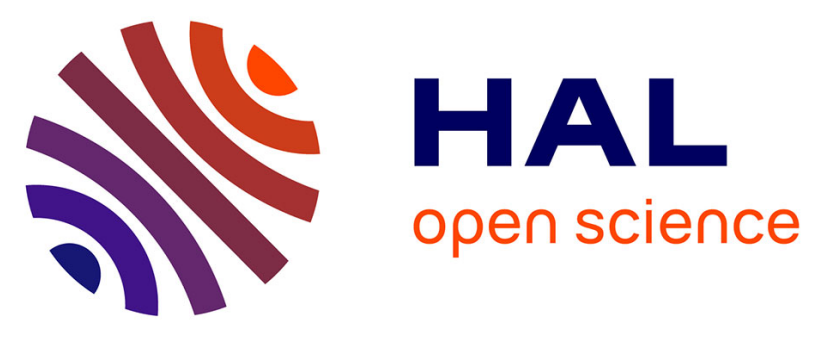

\title{
Method for screening antimicrobial gels against multi-species oral biofilms
}

Kanchana Chathoth, Bénédicte Martin, Martine Bonnaure-Mallet, Christine Baysse

\section{- To cite this version:}

Kanchana Chathoth, Bénédicte Martin, Martine Bonnaure-Mallet, Christine Baysse. Method for screening antimicrobial gels against multi-species oral biofilms. Journal of Microbiological Methods, 2021, 187, pp.106253. 10.1016/j.mimet.2021.106253 . hal-03282834

\section{HAL Id: hal-03282834 \\ https://hal.science/hal-03282834}

Submitted on 8 Sep 2021

HAL is a multi-disciplinary open access archive for the deposit and dissemination of scientific research documents, whether they are published or not. The documents may come from teaching and research institutions in France or abroad, or from public or private research centers.
L'archive ouverte pluridisciplinaire HAL, est destinée au dépôt et à la diffusion de documents scientifiques de niveau recherche, publiés ou non, émanant des établissements d'enseignement et de recherche français ou étrangers, des laboratoires publics ou privés. 
2 Kanchana Chathoth ${ }^{1}$, Bénédicte Martin ${ }^{1}$, Martine Bonnaure-Mallet ${ }^{1,2}$ and Christine Baysse ${ }^{1 *}$

3 *Corresponding author: christine.baysse@univ-rennes1.fr

$4 \quad{ }^{1}$ University of Rennes 1, NUMECAN INSERM U1241, CIMIAD F-35043 Rennes, France

$5 \quad 2$ CHU Pontchaillou, Rennes

6 Keywords: oral biofilm, antibacterial gels, Porphyromonas gingivalis, Treponema denticola,

7 Streptococcus gordonii, hyaluronic acid, oxygen, MBEC ${ }^{\mathrm{TM}}$ assay.

8 Running headline: In-vitro assay to evaluate gels against oral biofilm.

9

10 Abstract

11 We described a microtiter plate-based method that was effectively tailored for testing gel formulations against oral multispecies biofilms established on peg-lids. This method lifts the limitations imposed mainly by the anaerobic nature of the targeted bacterial species and the viscous properties of the targeted treatments.
5

Periodontitis is a polymicrobial chronic inflammatory disease of the periodontium caused by the accumulation of dental plaque (Pihlstrom et al., 2005). It is regarded as the second most common disease worldwide, with severe forms affecting up to 10 to $15 \%$ of adults (Petersen and Ogawa, 2012) resulting in tooth loss. Gel formulations of antibacterial agents are a promising delivery system for the treatment of periodontitis via topical administration. Their advantages 
21 include the ease of use, increased retention time at the site of application and controlled drug release. Several authors have demonstrated the effectiveness of gel formulations in reducing microbial content or plaque index (Gomes et al., 2006; Noyan et al., 1997; Paquette et al., 1997; Sauvêtre et al., 1993) in human, animal-based or in vitro studies. Similar improvement in probing depth and/or bleeding was reported (Esposito et al., 1996; Graça et al., 1997) on use of gel formulations alone or in conjunction with other modes of treatment. Our objective is to develop a process for high-throughput screening of the efficacy of gel-based formulations on a biofilm of oral bacteria.

The protocol is based on the model biofilm we previously established (Martin et al., 2018) which includes three key periodontal biofilm species. Streptococcus gordonii is a representative species of peroxygenic oral streptococci and produces hydrogen peroxide that can influence the pathogenic switch of the oral subgingival biofilm (Chathoth et al., 2020; Kreth et al., 2008). Whereas, Porphyromonas gingivalis and Treponema denticola, co-exist in deep periodontal pockets (Kigure et al., 1995; Kumawat et al., 2016) display a coaggregation reaction (Grenier, 1992) and are associated with severe forms of periodontitis. A recent theory proposed that the peroxygenic Streptococi (initial colonizers of dental plaque) and the sulfidogenic species such as P. gingivalis and T. denticola (pathogenic late colonizers) may act as the key players in a dysbiosis process (Chathoth et al., 2020). We therefore choose to implement an assay and test the effect of antimicrobial gels on this biofilm, considering the limitations imposed by both the anaerobic nature of the targeted bacterial species which prevent the use of classical Live/Dead stain or viability-PCR using PMA and the viscosity of the gels. The antimicrobial activity is evaluated by analysis of biofilm development after treatment by qPCR. The conversion of genomic DNA quantity to cells $\mathrm{ml}^{-1}$ was made possible by considering specific genome weights $\left(2.58 \times 10^{-6} \mathrm{ng}\right.$ for P. gingivalis, 
$3.12 \times 10^{-6} \mathrm{ng}$ for T. denticola and $2.41 \times 10^{-6} \mathrm{ng}$ for S. gordonii) as described by Ammann et al., (2013). In this study, the primers used to distinguish between species were (5'-> 3'): 16S S. gordonii F, AAG-CAA-CGC-GAA-GAA-CCT-TA;16S S. gordonii R, GTC-TCG-CTA-GAGTGC-CCA-AC; 16S P. gingivalis F, TGG-GTT-TAA-AGG-GTG-CGT-AG; 16S P. gingivalis R, CAA-TCG-GAG-TTC-CTC-GTG-AT; 16S T. denticola F, CGC-GTC-CCA-TTA-GCT-AGT-TG and 16S T. denticola R, TTC-TTC-ATT-CAC-ACG-GCG-TC.

The mixed biofilm was grown for 6 or 24 hours on saliva-coated pegs of Minimum Biofilm Elimination Concentration (MBEC ${ }^{\mathrm{TM}}$ ) Assay System (formerly the Calgary Biofilm Device) (Ceri et al., 1999) and challenged for 1 hour with two gels of similar viscosity already used for the treatment of oral infections. The method is described in Figure 1. Hyalugel ${ }^{\circledR}$-ADO (Ricerfarma, Milan, Italy) mainly consists of hyaluronic acid $(0.2 \%, \mathrm{w} / \mathrm{w})$; blue ${ }^{\circledR} \mathrm{m}$ oral gel (blue ${ }^{\circledR} \mathrm{m}$ Europe B.V., Netherlands) has the oxygen donor sodium perborate $(1.72 \%, w / w)$ and the iron chelator lactoferrin $(0.2 \%, \mathrm{w} / \mathrm{w})$ as main active ingredients (Shibli et al., 2021). A prior experiment using the agar diffusion method indicated that both gel formulations exhibited antibacterial activity against S. gordonii and P. gingivalis, with blue ${ }^{\circledR m}$ oral gel having better antibacterial activity than Hyalugel ${ }^{\circledR}-A D O($ Table S1).

In a preliminary assay to implement the method, the antimicrobial gels were tested on mature biofilms, grown for 24 hours. However, no significant change was observed in the ability of $P$. gingivalis and T. denticola to develop in the biofilm after the treatment for a further 24-hour incubation in comparison to the control treated with the growth medium MMBC-3 (Martin et al., 2018). Meanwhile, the biofilm growth of $S$. gordonii was severely affected by blue ${ }^{\circledR} \mathrm{m}$ oral gel, resulting in a dysbiosis with an increase in the ratio of anaerobic pathogens and a decreased total biomass in comparison to the control (Table S2). This indicated that the treatment with these gels 
could be effective as a preventive measure on a thinner biofilm. Therefore, we run the assays on 6hour biofilms.

The results corresponding to the treatment of a 6-hour biofilm are shown in Figure 2. Confocal fluorescent microscopy imaging of biofilms was performed as a qualitative test to ensure the presence of bacterial biofilm all over the pegs surface (Figure S1). The concentration of the total bacteria (biofilm + planktonic) was significantly reduced from $4.11 \times 10^{9}$ cells ml ${ }^{-1}$ in $\mathrm{MMBC}-$ 3 control to $5.15 \times 10^{6}$ cells $\mathrm{ml}^{-1}$ and $1.5 \times 10^{7}$ cells $\mathrm{ml}^{-1}$ for Hyalugel ${ }^{\circledR}$-ADO and blue ${ }^{\circledR} \mathrm{m}$ oral gel respectively after treatment of the biofilms for one hour (Figure 2A). The samples treated with Hyalugel ${ }^{\circledR}$-ADO and blue ${ }^{\circledR} \mathrm{m}$ oral gel displayed a biofilm reduction of $96.5 \%$ and $97.6 \%$ respectively, in comparison to untreated control (taken as $0 \%$ of reduction). This decrease in biofilm concentration due to Hyalugel ${ }^{\circledR}-\mathrm{ADO}$ and blue ${ }^{\circledR} \mathrm{m}$ oral gel is also evident in the microscopic images (Figure S1). Similarly, a decrease of over $99.5 \%$ was observed in the concentration of detached/planktonic cells on treatment with either of the gels in comparison to control (MMBC-3-treated samples) (Figure 2A). The biofilms on the peg surface (Figure 2B) and the corresponding planktonic (unattached or detached) (Figure 2C) cells contained a higher proportion of S. gordonii in comparison to P. gingivalis and T. denticola cells. The concentration of S. gordonii and T. denticola in the biofilm decreased significantly between the control samples and the samples treated with Hyalugel ${ }^{\circledR}-\mathrm{ADO}$ and blue ${ }^{\circledR m}$ oral gel, while the concentration of $P$. gingivalis remained unchanged. Hyalugel ${ }^{\circledR}-\mathrm{ADO}$ decreased the concentration of planktonic $S$. gordonii and P. gingivalis compared to controls while no effect was observed on T. denticola. blue ${ }^{\circledR m}$ oral gel induced a significant decrease in the concentration of planktonic S. gordonii cells and an increase in planktonic forms of $P$. gingivalis and $T$. denticola. These results indicate that both gels are effective in reducing biofilm development after a 1-hour treatment and that blue ${ }^{\circledR m}$ 
oral gel is additionally effective in inducing detachment of anaerobic pathogenic species. The method will then allow the number of product applications and the duration of the treatment to be refined in order to optimise the beneficial effects.

In conclusion, this method appears suitable to evaluate the antimicrobial effects of gels against a biofilm whose composition is relevant to predict the evolution of periodontitis. It allows high-throughput testing and is easy to use since antimicrobial activity is assessed by the ability of bacterial strains to grow after treatment. The use of qPCR allows monitoring of both the evolution of the total biofilm and the behaviour of each partner in the biofilm. The modulation of biofilm growth times and treatment exposure times will make it possible to refine the method on a caseby-case basis.

\section{Acknowledgements}

We thank blue ${ }^{\circledR} \mathrm{m}$ Europe B.V., Netherlands for sending us their product blue ${ }^{\circledR} \mathrm{m}$ oral gel, for this study and for product-related information. We also thank the manufacturer of Hyalugel ${ }^{\circledR}$-ADO, Ricerfarma (Milan, Italy) and the distributer, Laboratoire COOPER, Melun, France, for providing the product-related information. Our sincere gratitude to the Microscopy Rennes Imaging Center (Biosit) for their technical assistance for the microscopy experiments.

\section{References}

Ammann, T.W., Bostanci, N., Belibasakis, G.N., and Thurnheer, T. (2013). Validation of a quantitative real-time PCR assay and comparison with fluorescence microscopy and selective agar 
111 plate counting for species-specific quantification of an in vitro subgingival biofilm model. J.

112 Periodontal. Res. 48, 517-526. DOI: 10.1111/jre.12034.

114 Ceri, H., Olson, M.E., Stremick, C., Read, R.R., Morck, D., Buret, A., 1999. The Calgary Biofilm 115 Device: New Technology for Rapid Determination of Antibiotic Susceptibilities of Bacterial 116 Biofilms. J. Clin. Microbiol. 37, 1771-1776. doi: 10.1128/JCM.37.6.1771-1776.1999

118 Chan, E.C.S., Siboo, R., Keng, T., Psarra, N., Hurley, R., Cheng, S.-L., Iugovaz, I., 1993. 119 Treponema denticola (ex Brumpt 1925) sp. nov., nom. rev., and Identification of New Spirochete 120 Isolates from Periodontal Pockets. Int. J. Syst. Bacteriol. 43, 196-203. 121 https://doi.org/10.1099/00207713-43-2-196

123 Chathoth, K., Martin, B., Cornelis, P., Yvenou, S., Bonnaure-Mallet, M., Baysse, C., 2020. The 124 events that may contribute to subgingival dysbiosis: a focus on the interplay between iron, sulfide and oxygen. FEMS Microbiol. Lett. 367. https://doi.org/10.1093/femsle/fnaa100

127 Chen, C.C., Teng, L.J., Chang, T.C., 2004. Identification of clinically relevant viridans group 128 streptococci by sequence analysis of the 16S-23S ribosomal DNA spacer region. J. Clin. Microbiol. 129 42, 2651-2657. https://doi.org/10.1128/JCM.42.6.2651-2657.2004 
131 Esposito, E., Carotta, V., Scabbia, A., Trombelli, L., D’Antona, P., Menegatti, E., Nastruzzi, C., 132 1996. Comparative analysis of tetracycline-containing dental gels: Poloxamer- and monoglyceridebased formulations. Int. J. Pharm. 142, 9-23. https://doi.org/10.1016/0378-5173(96)04649-2

134

135 Gomes, B.P., Vianna, M.E., Sena, N.T., Zaia, A.A., Ferraz, C.C.R., de Souza Filho, F.J., 2006. In 136 vitro evaluation of the antimicrobial activity of calcium hydroxide combined with chlorhexidine 137 gel used as intracanal medicament. Oral Surg. Oral Med. Oral Pathol. Oral Radiol. Endodontology 102, 544-550. https://doi.org/10.1016/j.tripleo.2006.04.010

Graça, M.A., Watts, T.L.P., Wilson, R.F., Palmer, R.M., 1997. A randomized controlled trial of a $2 \%$ minocycline gel as an adjunct to non-surgical periodontal treatment, using a design with 142 multiple matching criteria. J. Clin. Periodontol. 24, 249-253. https://doi.org/10.1111/j.1600051X.1997.tb01838.x

145 Grenier, D., 1992. Demonstration of a bimodal coaggregation reaction between Porphyromonas 146 gingivalis and Treponema denticola. Oral Microbiol Immunol Oct;7(5):280-4. DOI: 10.1111/j.1399-302x.1992.tb00589.x

149 Kigure, T., Saito, A., Seida, K., Yamada, S., Ishihara, K., Okuda, K., 1995. Distribution of 150 Porphyromonas gingivalis and Treponema denticola in human subgingival plaque at different 
151 periodontal pocket depths examined by immunohistochemical methods. J. Periodontal Res. 30, 152 332-341. https://doi.org/10.1111/j.1600-0765.1995.tb01284.x

154 Kreth, J., Zhang, Y., Herzberg, M.C., 2008. Streptococcal Antagonism in Oral Biofilms: 155 Streptococcus sanguinis and Streptococcus gordonii Interference with Streptococcus mutans. J. 156 Bacteriol. 190, 4632-4640. https://doi.org/10.1128/JB.00276-08

158 Kumawat, R.M., Ganvir, S.M., Hazarey, V.K., Qureshi, A., Purohit, H.J., 2016. Detection of 159 Porphyromonas gingivalis and Treponema denticola in chronic and aggressive periodontitis 160 patients: A comparative polymerase chain reaction study. Contemp. Clin. Dent. 7, 481-486. 161 https://doi.org/10.4103/0976-237X.194097

Martin, B., Tamanai-Shacoori, Z., Bronsard, J., Ginguené, F., Meuric, V., Mahé, F., and BonnaureMallet, M., 2017. A new mathematical model of bacterial interactions in two-species oral biofilms. PLOS ONE 12, e0173153. DOI: 10.1371/journal.pone.0173153.

166

167 Martin, B., Chathoth, K., Ouali, S., Meuric, V., Bonnaure-Mallet, M., Baysse, C., 2018. New 168 growth media for oral bacteria. J. Microbiol. Methods 153, 10-13. 169 https://doi.org/10.1016/j.mimet.2018.08.013 
171 Noyan, Ü., Yilmaz, S., Kuru, B., Kadir, T., Acar, O., Büget, E., 1997. A clinical and 172 microbiological evaluation of systemic and local metronidazole delivery in adult periodontitis 173 patients. J. Clin. Periodontol. 24, 158-165. https://doi.org/10.1111/j.1600-051X.1997.tb00485.x

175 Paquette, D.W., Waters, G.S., Stefanidou, V.L., Lawrence, H.P., Friden, P.M., O'Connor, S.M., 176 Sperati, J.D., Oppenheim, F.G., Hutchens, L.H., Williams, R.C., 1997. Inhibition of experimental 177 gingivitis in beagle dogs with topical salivary histatins. J. Clin. Periodontol. 24, 216-222. https://doi.org/10.1111/j.1600-051X.1997.tb01834.x with chronic disease prevention and control: Global periodontal health. Periodontol. 2000 60, 1539. https://doi.org/10.1111/j.1600-0757.2011.00425.x

Pihlstrom, B.L., Michalowicz, B.S., Johnson, N.W., 2005. Periodontal diseases. Lancet Lond. Engl. 366, 1809-1820. https://doi.org/10.1016/S0140-6736(05)67728-8

187 Sauvêtre, E., Glupczynsky, Y., Labbé, M., Yourassowsky, E., Sauvêtre, E., Pourtois, M., 1993. 188 The effect of clindamycin gel insert in periodontal pockets, as observed on smears and cultures. 189 Infection 21, 245-247. https://doi.org/10.1007/BF01728900 
Shibli, J.A., Rocha, T.F., Coelho, F., de Oliveira Capote, T.S., Saska, S., Melo, M.A., Pingueiro, J.M.S., de Faveri, M., Bueno-Silva, B., 2021. Metabolic activity of hydro-carbon-oxo-borate on a multispecies subgingival periodontal biofilm: a short communication. Clin. Oral Investig. https://doi.org/10.1007/s00784-021-03900-0

Watanabe, T., Maruyama, F., Nozawa, T., Aoki, A., Okano, S., Shibata, Y., Oshima, K., Kurokawa, K., Hattori, M., Nakagawa, I., Abiko, Y., 2011. Complete Genome Sequence of the Bacterium Porphyromonas gingivalis TDC60, Which Causes Periodontal Disease. J. Bacteriol. 193, 42594260. https://doi.org/10.1128/JB.05269-11

\section{Legends of figures}

Figure 1. The different steps of the method for screening the effectiveness of gels on a biofilm of oral bacteria. Strains of Streptococcus gordonii Challis DL1 (Chen et al., 2004), Porphyromonas gingivalis TDC60 (Watanabe et al., 2011) and Treponema denticola ATCC35405 (Chan et al., 1993) were used for the study. The lid with pegs (Nunc-TSP, polystyrene) was placed over the microtiter plate and incubated in filter-sterilised saliva that was diluted twice in sterile distilled water (Normal Saliva Human Fluid, Pool Human Donors, MyBioSource) for 30 minutes. The saliva-coated pegs were immersed in $200 \mu 1$ of inoculum consisting of S. gordonii $\left(\mathrm{OD}_{600 \mathrm{~nm}}: 0.05\right)$, P. gingivalis $\left(\mathrm{OD}_{600 \mathrm{~nm}}: 0.1\right)$ and $T$. denticola $\left(\mathrm{OD}_{600 \mathrm{~nm}}: 0.1\right)$ and incubated in anaerobic conditions for 6 or 24 hours at $37^{\circ} \mathrm{C}$. The 6-hour or 24-hour three-species biofilms or adherent cells present on the surface of the pegs were subjected to $150 \mu \mathrm{L}$ of either MMBC-3 or Hyalugel ${ }^{\circledR}$-ADO or blue ${ }^{\circledR} \mathrm{m}$ oral gel for 1 hour in anaerobic condition at $37^{\circ} \mathrm{C}$. The pegs were then 
incubated in a new microtiter well containing $200 \mu \mathrm{l}$ of MMBC-3 for 24 hours in anaerobic

conditions at $37^{\circ} \mathrm{C}$. The detached/planktonic cells were collected from the microtiter plate and the biofilm were collected from the surface of the pegs by sonication ( $30 \mathrm{~min}$ ) and were quantified by qPCR as previously described (Martin et al., 2017). Six pegs (two per condition) were also kept for microscopic visualisation.

Figure 2. qPCR quantification of the number of bacteria (cells $\mathrm{ml}^{-1}$ ) in the biofilm (collected from the pegs) and in planktonic form (collected from the 96-well microtiter plate). The 6hour three-species biofilm on the pegs were subjected to MMBC-3 or Hyalugel ${ }^{\circledR}$-ADO or blue ${ }^{\circledR} \mathrm{m}$ oral gel for 1 hour and further incubated in MMBC-3 for 24 hours. The planktonic cells were collected from the 96-well plate while the biofilm was collected from the pegs and quantified. (A) Total concentration (cells ml-1) of bacteria (planktonic/detached + biofilm), bacteria in biofilm and bacteria detached or in planktonic form after each treatment. (B) Concentration of each species in the biofilm after each treatment. (C) Concentration of each species in planktonic/ detached cells for each treatment. White bars $=$ MMBC-3, grey bars $=$ Hyalugel ${ }^{\circledR}-A D O$ and black bars $=$ blue ${ }^{\circledR} \mathrm{m}$ oral gel. p-value $<0.05=*$, p-value $<0.01=* *$, p-value $<0.001=* * *$

Figure S1. Representative microscopic images of the 6-hour three-species oral biofilm on the surface of the pegs. Post 1-hour treatment (with MMBC-3, Hyaluge ${ }^{\circledR}-A D O$ or blue ${ }^{\circledR}$ m oral gel) of the 6-hour biofilms on the surface of the pegs, the pegs were incubated in MMBC-3 for 24 hours. The pegs were further broken from the lid using pliers and stained using Styo ${ }^{\circledR} 9$. The stained pegs were visualized using the Leica TCS-SP5 confocal laser scanning microscope. To compare 
235 between the three treatments, maximum z-production of the $\mathrm{Z}$ stack were taken using $10 \mathrm{X}$ oil 236 immersion objective lens and numerical zoom of 2: (A), (B), (C). Magnified images were captured 237 using the $63 \mathrm{X}$ oil immersion objective lens, numerical zoom of 5.05: (D), (E), (F).

238

239

240

241 


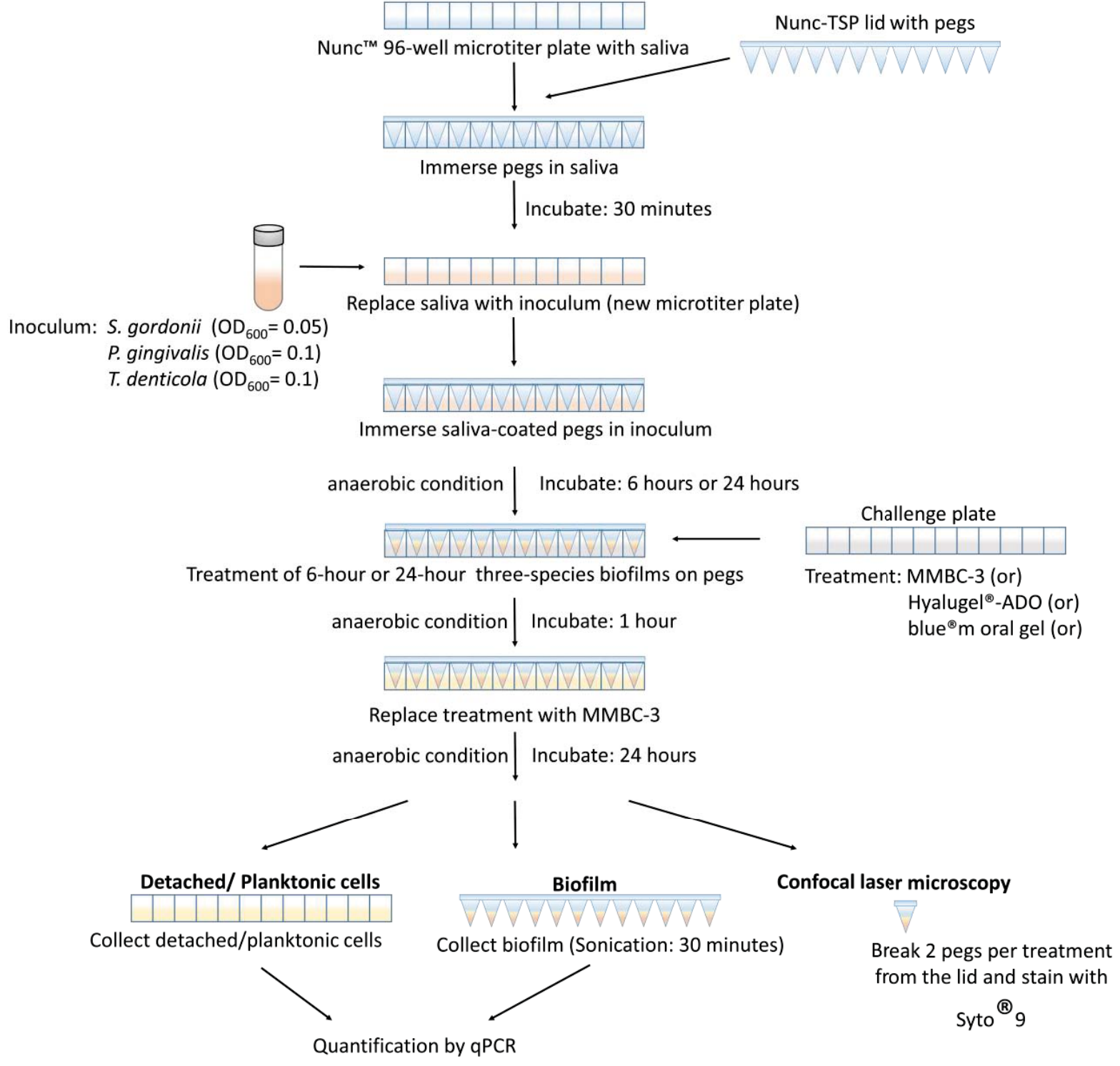


A

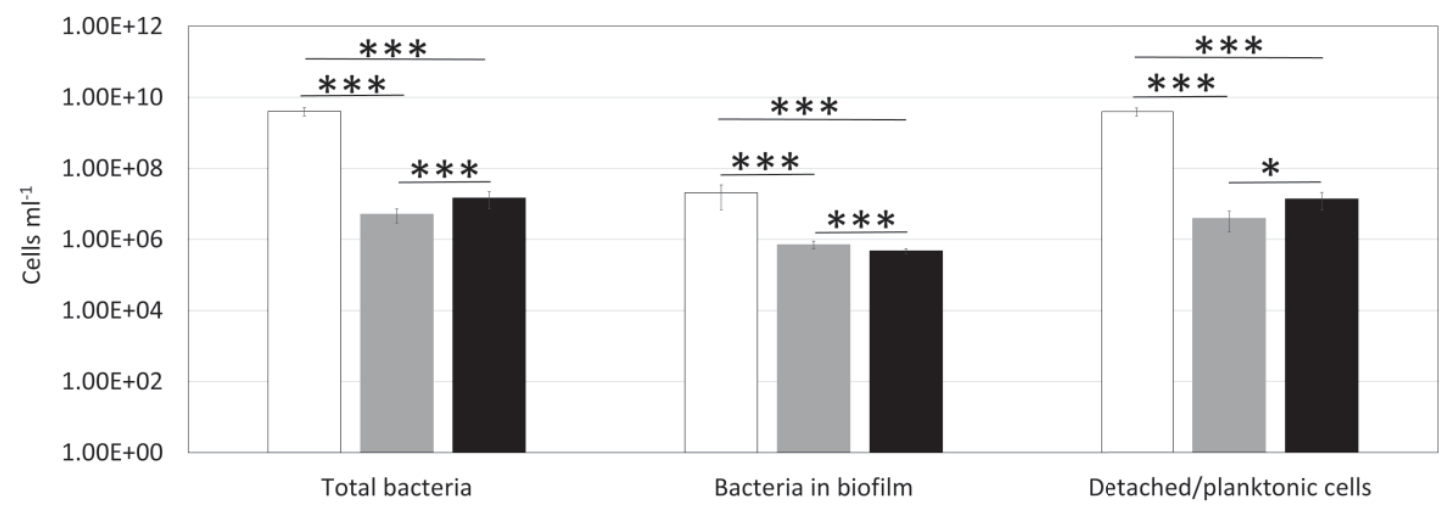

B

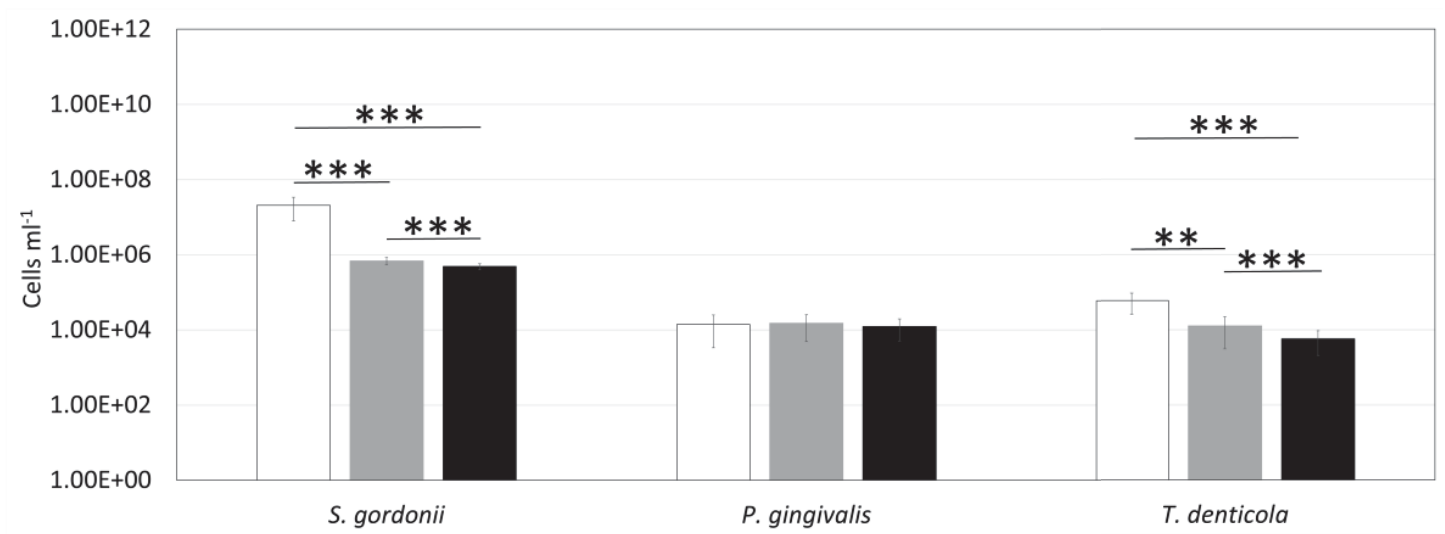

C

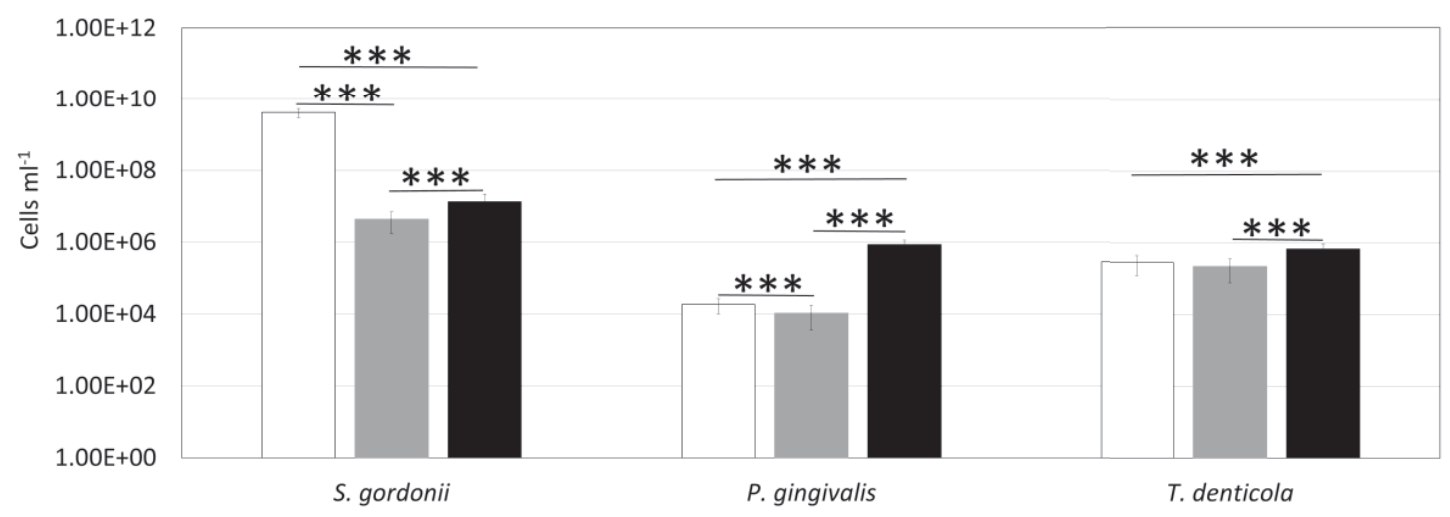

$248 \quad$ Figure 2 